\title{
Use of eugenol for anesthesia of lesser guitarfish Zapteryx brevirostris (Rhinobatidae)
}

\author{
V. Takatsuka ${ }^{a}$, D. G. C. Costa ${ }^{a}$, N. Y. Oliveira ${ }^{a}$, E. G. Sanches ${ }^{a}$ and V. G. Azevedo ${ }^{a *}$ \\ ${ }^{a}$ Núcleo de Pesquisa e Desenvolvimento do Litoral Norte, Instituto de Pesca, \\ Estrada Joaquim Lauro de Monte Claro Neto, 2275, CEP 11680-000, Ubatuba, SP, Brasil \\ *e-mail: vazevedo@pesca.sp.gov.br
}

Received: October 18, 2017 - Accepted: February 8, 2018 - Distributed: August 31, 2019

(With 1 figure)

\begin{abstract}
Anesthesia can be utilized as a non-lethal procedure to allow easy handling of teleosts and elasmobranchs in captivity or in the wild. For this, anesthetic protocols need to be established according to the species. The aim of this study was to determine the ideal concentration of eugenol for anesthesia of Zapteryx brevirostris. Four concentrations were tested: $21.25,42.50,85.00$ and $170.00 \mathrm{mg} \mathrm{L}^{-1}$ (ratio of 1:5 with absolute ethanol). The perfect concentration of eugenol for this species was $85.0 \mathrm{mg} \mathrm{L}^{-1}$, which enabled up to 300 seconds of work on the fish, without any response to handling.

Keywords: sedation, anesthetic, ray, elasmobranch.
\end{abstract}

\section{Uso de eugenol para anestesia de raia-viola Zapteryx brevirostris (Rhinobatidae)}

\begin{abstract}
Resumo
A anestesia pode ser utilizada como um procedimento não letal que facilita o manejo de teleósteos e elasmobrânquios de cativeiro e de vida livre. Para isso, protocolos anestésicos devem ser estabelecidos de acordo com a espécie. O objetivo deste trabalho foi determinar a concentração ideal do eugenol para anestesiar Zapteryx brevirostris. Foram testadas as concentrações de 21,25; 42,50; 85,00 e 170,00 $\mathrm{mg} \mathrm{L}^{-1}$ (1:5 de álcool absoluto). A concentração de $85,0 \mathrm{mg} \mathrm{L}^{-1} \mathrm{de}$ eugenol foi a mais adequada para a espécie, permitindo uma janela de trabalho de até trezentos segundos com o animal não respondendo ao manejo.
\end{abstract}

Palavras-chave: sedação, anestesia, raia, elasmobrânquio.

\section{Introduction}

Handling of elasmobranchs in captivity or in the natural environment requires complicated logistics that impose major difficulty. Their behavior of resistance during capture and handling has an effect on their physiology. Therefore, it is important to immobilize these fish before handling, especially if it is desired to evaluate their physiology or avoid stress (Souza et al., 2017). Anesthesia and sedation are valuable tools in relation to catching wild fish. In operations to colonize aquariums, it is not always necessary to anesthetize or sedate the fish. However, for some procedures, sedation is essential for minimizing the stress (Weinert et al., 2015) or physical damage that is caused through capture, biometry (Husen and Sharma, 2014) and transportation (Simões et al., 2011; Rucinque et al., 2016). For research or veterinary procedures, anesthesia or sedation to keep the animal unconscious or to relieve pain may be necessary (Ross and Ross, 2008).

The process of anesthesia can be divided in four stages or levels: 1. light sedation; 2. deep sedation;
3. anesthesia (Woody et al., 2002); and (added by some authors) 4. overdose or euthanasia (Ross and Ross, 2008). Each stage has been described in terms of the different behaviors observed, and it is therefore possible to monitor the evolution of anesthesia and know when to intervene to perform veterinary procedures.

Recent research on teleosts has tested natural anesthetics derived from plant oils (Sanchez et al., 2014). Among these, clove oil is extracted from the flowers, stalks and leaves of Syzygium aromaticum (Eugenia aromaticum) or Eugenia caryophyllata. Use of clove oil as an anesthetic for teleosts is widespread and well-established (Keene et al., 1998; Griffiths, 2000; Delbon and Ranzani-Paiva, 2012; Pádua et al., 2013; Shijie et al., 2016; Fernandes et al., 2016; Pattanasiri et al., 2017). The drugs used for immersion anesthesia for elasmobranchs are the following: benzocaine, etomidate, metomidate, halothane-oxygen-nitrous oxide, oxygen, quinaldine and tricaine methane sulfonate (MS-222) (Stamper, 2004; Stamper, 2007). However, this group 
includes carcinogenic substances, substances that irritate the fish mucosa, some that have a high commercial price and some that are prohibited in Brazil (Roubach et al., 2001).

In considering the use of natural anesthetics derived from plant oils for elasmobranchs, the use of the Eugenol, is an option. The objective of this work is to test the use of the Eugenol as anesthetics for elasmobranchs and to determine the ideal concentration for anesthesia of Zapteryx brevirostris.

\section{Methods}

For this experiment, 21 adult specimens of lesser guitarfish (11 male rays and 10 female rays) were used. Their mean weight was $541.16 \pm 119.18 \mathrm{~g}$ and their mean total length was $44.47 \pm 4.48 \mathrm{~cm}$. The small number of specimens that were used in this experiment was related to the physical limitations of the laboratory and the size of these fish.

The fish were obtained through a trawl fishery focusing on shrimps in Ubatuba, SP, under authorization via SISBIO no. 49980-3 and from our institution's biosafety and ethics committee (Comitê de Ética em Experimentação Animal do Instituto de Pesca, CEEAIP), no. 12/2016. After recovery of the trawl net, the rays were removed from the bagger and were placed together in a large Styrofoam box with continuous water flow until the time of landing, in front of the Marine Pisciculture Laboratory. There, the rays were acclimatized and maintained in three circular fiberglass tanks with a capacity of $3000 \mathrm{~L}$, at a density of seven rays per tank (approximately $1 \mathrm{~kg} \mathrm{~m}^{-3}$ ) and at a temperature of $25 \pm 2{ }^{\circ} \mathrm{C}$ and salinity of $30 \pm 1$.

Each tank had a sump filtration system of $100 \mathrm{~L}$, with a skimmer and a bag of mesh size 100 microns. All the water in each tank was filtered every 45 minutes. Feed was offered once a day in the morning, consisting of Atlantic seabob shrimp (Xiphopenaeus kroyeri) without head and Frigate tuna (Auxis thazard) in cubes, at the amount of $1 \%$ of the biomass of the tank. Food leftovers and feces were siphoned out, 5 minutes after feeding started.

For anesthesia, four plastic boxes of capacity $100 \mathrm{~L}$, containing $20 \mathrm{~L}$ of water for anesthetic dilution, were prepared. Eugenol (K-Dent) was previously diluted in 95\% ethanol (ratio of 1:5). The concentrations of eugenol tested were $21.25,42.50,85.00$ and $170.00 \mathrm{mg} \mathrm{L}^{-1}$.

The rays were sorted and immersed individually in each concentration of anesthetic solution: 6 rays in $21.25 \mathrm{mg} \mathrm{L}^{-1}, 5$ in $42.50 \mathrm{mg} \mathrm{L}^{-1}, 5$ in $85.00 \mathrm{mg} \mathrm{L}^{-1}$ and 5 in $170.00 \mathrm{mg} \mathrm{L}^{-1}$. The chronometer was triggered to establish the time taken to induce anesthesia, which was counted from the time of transferring the ray to the tank containing eugenol, until anesthesia stage III was reached (Table 1) (Woody et al., 2002; Ross and Ross, 2008). At this stage, the rays displayed tonic immobility, absence of tail and fin movements, absence of reaction to external touch and frequency of spiracle beats of less than 10 per minute.

After reaching stage III, each ray was transferred to a $30 \mathrm{~L}$ plastic box containing seawater, and the anesthesia recovery period began. Biometry was performed while the ray was in this box and, afterwards, it was transferred to a box containing $100 \mathrm{~L}$ of water for final recovery monitoring. The anesthesia recovery time was monitored until the ray exhibited normal swimming movements and the frequency of the spiracle beats reached the same level as in the first measurement before induction of anesthesia. The sequence of behaviors exhibited comprised: immobile animal, slow swimming, contraction of the gills, normal swimming, excitation, tail-only movement and flushing redness. During the handling period, all the behaviors exhibited were recorded, and the rate of spiracle movement was measured every 60 seconds. It was established that the times taken for induction of and recovery from anesthesia should not be longer than 600 seconds, longer than recommended time for anesthesia of aquatic organisms, for which the induction time should be 180 seconds and recovery time 300 seconds (Keene et al., 1998).

Based on our observation of the behaviors exhibited by the rays during the anesthesia baths, we suggest that for elasmobranchs some adaptations should be made to the tables that are used for evaluating anesthesia among teleosts. Because of differences in anatomy and ethology, we had to modify the descriptions of characteristics observed at each anesthetic stage.

The data were analyzed regarding normality of distribution using the Shapiro-Wilk test, and the Bartlett test was used for homogeneity of variance (homoscedasticity). The data were then subjected to the ANOVA test and, in situations

Table 1. Description of stages of anesthesia for Zapteryx brevirostris using different concentrations of eugenol.

\begin{tabular}{|c|c|c|}
\hline Stage & Description & Observed behaviors \\
\hline $\mathrm{I}$ & Induction & $\begin{array}{l}\text { Reduction of response to external stimuli, loss of partial balance. Animal static, exhibiting } \\
\text { contraction movements in the region of the gills, onset of pectoral fin hyperemia. }\end{array}$ \\
\hline II & Excitation & $\begin{array}{l}\text { Loss of movements and hyperexcitation chapters. It can lead to uncontrolled movements like } \\
\text { a violent and uncoordinated swimming. }\end{array}$ \\
\hline III & Anesthesia & $\begin{array}{l}\text { Total loss of reaction to external stimuli, even if strong, almost absent ventilation, total loss } \\
\text { of muscle tone. }\end{array}$ \\
\hline \multirow[t]{2}{*}{ IV } & Overdose & Respiratory arrest, walking towards euthanasia. \\
\hline & Recovery & $\begin{array}{l}\text { Return of the frequency of the spiracle beats, lateral movements of the tail and dorsal fins } \\
\text { and movement through the enclosure. }\end{array}$ \\
\hline
\end{tabular}

Adapted from Keene et al. (1998), Ross and Ross (2008) and Woody et al. (2002). 
of significant differences, the Tukey test was also used. The significance level was taken to be $5 \%$. Regression analysis was performed between eugenol concentration, induction times and anesthesia recovery.

\section{Results}

Throughout the operation, the individual fish behavior was noted. Summaries of the anesthesia induction ethograms at each concentration of eugenol are presented in the following.

\section{a) $\mathbf{2 1 . 2 5} \mathrm{mg} \mathrm{L}^{-1}$}

Marginal hyperemia of the pectoral and pelvic fins; increased beating of the spiracle; variation in motor activity with hyperexcitation phase; and contraction in the gill region, for expulsion of water through the spiracles. The rays did not reach stage III of anesthesia and remained conscious and agitated.

\section{b) $42.50 \mathrm{mg} \mathrm{L}^{-1}$}

Marginal hyperemia of the pectoral and pelvic fins; increased beating of the spiracle; variation in motor activity with hyperexcitation phase; and contraction in the gill region, for expulsion of water through the spiracles. Reduction of motor activity, resulting in only quiet lateral movements of tail and dorsal fins; hyperemia of fins present. The rays reached stage III of anesthesia: they did not react to handling and remained totally relaxed during the biometry.

\section{c) $85.00 \mathrm{mg} \mathrm{L}^{-1}$}

Increased beating of the spiracle; variation in motor activity with swimming phases; and contraction in the gill region, for expulsion of water through the spiracles; hyperemia of fins present. After 120 seconds, there was a drastic reduction of spiracle beats, such that there was minimal reaction to external stimuli of touch, and biometrics were performed at this time.

\section{d) $170.00 \mathrm{mg} \mathrm{L}^{-1}$}

Excitement phase; drastic reduction of spiracle beats; hyperemia of fins present, but less intensely than at other concentrations. The rays reached stage III of anesthesia, and biometrics were performed at this time.

The results relating to induction and recovery times are listed in Table 2.
The template that was found for induction and recovery of rays anesthetized with eugenol followed the equations $\mathrm{Ti}=-1.1810 \mathrm{x}+1.9150$ and $\mathrm{Tr}=0.1943 \mathrm{x}+0.1125$, in which $\mathrm{Ti}$ is the time needed to reach stage III in seconds, and $\mathrm{Tr}$ is the time taken for recovery in seconds. For the induction equation, $\mathrm{R}^{2}$ was 0.7882 and for the recovery equation it was 0.4006 .

After anesthesia recovery, the rays were monitored for 72 hours in a 3000 L glass fiber tank with oxygenation and constant filtration to follow up their return to appetite and any mortality. The first meal was offered 24 hours after recovery from anesthesia, and it was observed that the consumption was not different from the amount prior to the experiment $(50 \mathrm{~g})$. There was no mortality during or after the experiment.

\section{Discussion}

Use of low dosages of eugenol did not allow the ideal anesthetic plane for safe handling (stage III) to be reached. Instead of producing the desired effects, low dosages gave rise to exacerbated and uncoordinated behaviors among rays, along with increased beating of the spiracle. These features are characteristic of stage II of anesthesia (Woody et al., 2002).

Fish should not be kept at this stage for a long time, because this is a stage of unnecessary suffering due to the hyperexcitation that it causes, which can result in vomiting, respiratory arrest and pupillary dilatation (Ross and Ross, 2008). One way to avoid these effects is to increase the dose of anesthetic, thus leading the fish to stage III. In teleosts, stage II of anesthesia through use of eugenol was also observed, in the concentration of $40 \mathrm{mg} \mathrm{L}^{-1}$ (Delbon and Ranzani-Paiva, 2012).

By increasing the eugenol dose to $42.50 \mathrm{mg} \mathrm{L}^{-1}$, the rays also entered stage II, but after some minutes, stage III was reached. This resulted in a mean induction time of $434.4 \mathrm{~s}$, which can be considered long. The ideal would be 180 to 300 seconds (Keene et al., 1998).

The muscle contractions in the gill region that were exhibited at the two lowest concentrations used suggest that the conscious rays identified the drug. Moreover, in an attempt to expel this substance, they contract the musculature, thus resulting in squirting water out, which was detected as a slight movement on the surface of the water.

The two highest concentrations tested successfully induced stage III anesthesia in the rays. However, the concentration that induced anesthesia within the time closest to the ideal (Keene et al., 1998) was $85.00 \mathrm{mg} \mathrm{L}^{-1}$.

Table 2. Induction and recovery times (s) to Zapteryx brevirostris in different eugenol concentration.

\begin{tabular}{ccc}
\hline Eugenol $\left(\mathbf{m g ~ L}^{-1}\right)$ & Induction time (Stage III) & Recovery time \\
\hline 21.25 & $>600 \mathrm{~s}^{\mathrm{d}}$ & - \\
42.50 & $434.4 \mathrm{~s} \pm 64.8 \mathrm{~s}^{\mathrm{c}}$ & $328.8 \mathrm{~s} \pm 50 \mathrm{~s}^{\mathrm{a}}$ \\
85.00 & $183.6 \mathrm{~s} \pm 54 \mathrm{~s}^{\mathrm{b}}$ & $254.4 \mathrm{~s} \pm 89.4 \mathrm{~s}^{\mathrm{a}}$ \\
170.00 & $74.4 \mathrm{~s} \pm 33 \mathrm{~s}^{\mathrm{a}}$ & $434.4 \mathrm{~s} \pm 208.2 \mathrm{~s}^{\mathrm{b}}$ \\
\hline
\end{tabular}

Average and standard deviation. Different letters in the same column means difference between treatments. 
With this, stage II of anesthesia and its unwanted behaviors was avoided and the rays became anesthetized and ready for biometrics and routine management in 183.6 seconds. The safety of this concentration was confirmed through the recovery time, which was very close to the ideal for recovery from anesthesia and was an average of 254.4 seconds.

Using $170 \mathrm{mg} \mathrm{L}^{-1}$ the induction time was faster, with a mean of 74.4 seconds. A few more seconds of immersion in the anesthetic resulted in a longer recovery period. This demonstrates that the safety margin is low and therefore that in situations of anesthetization in which euthanasia is not the aim, concentrations as high as this are not recommended.

The window for doing work during management using the dose of $85 \mathrm{mg} \mathrm{L}^{-1}$ was 180 to 300 seconds. This was sufficient time for blood collection, inspection of ectoparasites and body lesions and complete biometry on the individual. Result like this were also found by Frick et al. (2009) using Port Jackson sharks and Australian swellsharks.

The adjusted regression curve for the anesthesia induction time showed that there was a linear reduction in induction time with increasing eugenol concentration (Figure 1). In other words, the higher the concentration of eugenol used was, the shorter the anesthesia induction time also was. This behavior was also found among juveniles of Nile tilapia (Oreochromis niloticus), and $40 \mathrm{mg} \mathrm{L}^{-1}$ gave rise to the longest induction time (Delbon and Ranzani-Paiva, 2012).

The period monitored after recovery from anesthesia suggests that like in teleosts (Delbon and Ranzani-Paiva, 2012), eugenol is a safe and quickly eliminated substance when used in elasmobranchs. Twenty-four hours after recovery from anesthesia, the rays were found to feed in a normal manner. Therefore, successive administration of eugenol in elasmobranchs should be investigated: this has already been proven to be possible in teleosts (Woody et al., 2002; Delbon and Ranzani-Paiva, 2012; Guénette et al., 2007). The present study reaffirms the safety of this drug, which is still very little used for management of marine elasmobranchs.

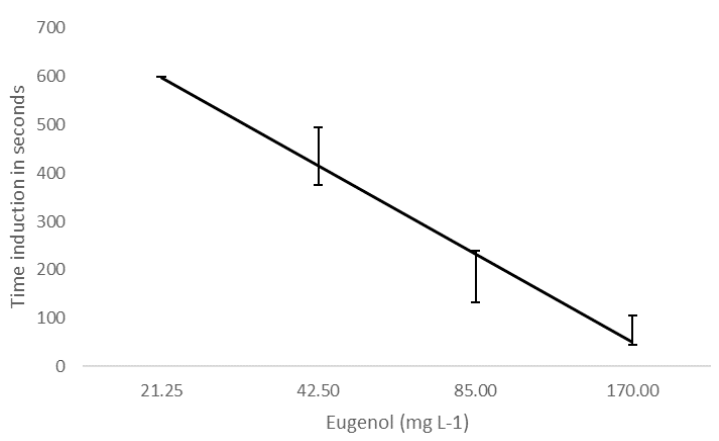

Figure 1. Regression curve adjusted for the time of anesthetic induction in Lesser Guitarfish Zapteryx brevirostris, submitted to different concentrations of eugenol. Error bar represents the standard deviation.

\section{Conclusions}

Eugenol can be safely used as an anesthetic substance for elasmobranchs. For routine procedures in which this anesthetic is used to reduce stress in these fish and to facilitate professional handling, the ideal is $85 \mathrm{mg} \mathrm{L}^{-1}$, because this presents an induction time of around 180 seconds and a recovery time of 240 seconds.

\section{References}

DELBON, M.C. and RANZANI-PAIVA, M.J.T., 2012. Eugenol in tilapia juvenile: concentrations and successive administrations. Boletim do Instituto de Pesca, vol. 38, no. 1, pp. 43-52.

FERNANDES, I.M., BASTOS, Y.F., BARRETO, D.S., LOURENÇO, L.S. and PENHA, J.M., 2016. The efficacy of clove oil as an anaesthetic and in euthanasia procedure for smallsized tropical fishes. Brazilian Journal of Biology $=$ Revista Brasileira de Biologia, vol. 77, no. 3, pp. 444-450. http://dx.doi. org/10.1590/1519-6984.15015. PMid:27683808.

FRICK, L.H., REINA, R.D. and WALKER, T.I., 2009. The physiological response of Port Jackson Sharks and Australian Swellsharks to sedation, gill-net capture, and repeated sampling in captivity. North American Journal of Fisheries Management, vol. 29, no. 1, pp. 127-139. http://dx.doi.org/10.1577/M08-031.1.

GRIFFITHS, S.P., 2000. The use of clove oil as an anaesthetic and method for sampling intertidal rockpool fishes. Journal of Fish Biology, vol. 57, no. 6, pp. 1453-1464. http://dx.doi. $\operatorname{org} / 10.1111 /$ j. 1095-8649.2000.tb02224.x.

GUÉNETTE, S.A., UHLAND, F.C., HÉLIE, P., BEAUDRY, F. and VACHON, P., 2007. Pharmacokinetics of eugenol in rainbow trout (Oncorhynchus mykiss). Aquaculture, vol. 266, no. 1-4, pp. 262-265. http://dx.doi.org/10.1016/j.aquaculture.2007.02.046.

HUSEN, A. and SHARMA, S., 2014. Efficacy of anesthetics for reducing stress in fish during aquaculture practices - a review. Journal of Science, Engineering and Technology, vol. 10, no. 1, pp. 104-123.

KEENE, J.L., NOAKES, D.L.G., MOCCIA, R.D. and SOTO, C.G., 1998. The efficacy of clove oil as an anaesthetic for rainbow trout, Oncorhynchus mykiss (Walbaum). Aquaculture Research, vol. 29, no. 2, pp. 89-101. http://dx.doi.org/10.1111/j.1365-2109.1998. tb01113.x.

PÁDUA, S.B., DIAS NETO, J., SAKABE, R., CLAUDIANO, G.S., CHAGAS, E.C. and PILARSKI, F., 2013. Variáveis hematológicas em tambaquis anestesiados com óleo de cravo e benzocaína. Pesquisa Agropecuária Brasileira, vol. 48, no. 8, pp. 1171-1174. http://dx.doi.org/10.1590/S0100-204X2013000800056.

PATTANASIRI, T., TAPARHUDEE, W. and SUPPAKUL, P., 2017. Acute toxicity and anaesthetic effect of clove oil and eugenol on Siamese fighting fish, Betta splendens. Aquaculture International, vol. 25, no. 1, pp. 163-175. http://dx.doi.org/10.1007/ s10499-016-0020-2.

ROSS, L.G. and ROSS, B., 2008. Anaesthetic and sedative techniques for aquatic animals. 3rd ed. Oxford: Blackwell Publishing, 222 p. http://dx.doi.org/10.1002/9781444302264.

ROUBACH, R., GOMES, L.C. and VAL, A.L., 2001.2001 Safest level of tricaine methanesulfonate (MS-222) to induce anesthesia in juveniles of matrinxã, Brycon cephalus. Acta Amazonica, 
vol. 31, no. 1, pp. 159-163. http://dx.doi.org/10.1590/180943922001311163.

RUCINQUE, D.S., POLO, G., BORBÓN, J. and GONZÁLEZ MANTILLA, J.F., 2016. Anesthetic use of eugenol and benzocaine in juveniles of red tilapia (Oreochromis sp.). Revista Colombiana de Ciencias Pecuarias, vol. 30, no. 1, pp. 60-66. http://dx.doi. org/10.17533/udea.rccp.v30n1a07.

SANCHEZ, M.S.S., RODRIGUES, R.A., NUNES, A.L., OLIVEIRA, A.M.S., FANTINI, L.E. and CAMPOS, C.M., 2014. Respostas fisiológicas de cacharas Pseudoplatystoma reticulatum submetidos a anestésicos naturais. Semina: Ciências Agrárias, vol. 35, no. 2, pp. 1061-1070. http://dx.doi.org/10.5433/1679$0359.2014 \mathrm{v} 35 \mathrm{n} 2 \mathrm{p} 1061$.

SHIJIE, L., ADAMS, M.B.A., NOWAK, B.F.A. and CROSBIE, P.B.B., 2016. Effects of anaesthetics containing eugenol on Neoparamoeba perurans. Aquaculture, vol. 463, pp. 159-162. http://dx.doi.org/10.1016/j.aquaculture.2016.05.033.

SIMÕES, L.N., LOMBARDI, D.C., GOMIDE, A.T.M. and GOMES, L.C., 2011. Efficacy of clove oil as anesthetic in handling and transportation of Nile tilapia, Oreochromis niloticus (Actinopterygii: Cichlidae) juveniles. Zoologia, vol. 28, no. 3, pp. 285-290. http://dx.doi.org/10.1590/S1984-46702011000300001.

SOUZA, C.D., BALDISSERA, M.D., SALBEGO, J., LOPES, J.M., VAUCHER, R.D., MOURAO, R.H.V., CARON, B.O.,
HEINZMANN, B.M., SILVA, L.V.F. and BALDISSEROTTO, B., 2017. Physiological responses of Rhamdia quelen (Siluriformes: Heptapteridae) to anesthesia with essential oils from two different chemotypes of Lippia alba. Neotropical Ichthyology, vol. 15, no. 1, pp. e160083. http://dx.doi.org/10.1590/1982-0224-20160083.

STAMPER, M.A., 2004. Immobilization on elasmobranchs. In: M. SMITH, D. WARMOLTS, D. THONEY and R. HUETER, eds. The elasmobranch husbandry manual: captive care of sharks, rays, and their relatives. 1st ed. Columbus: Biological Survey, pp. 301-323.

STAMPER, M.A., 2007. Elasmobranchs: sharks, rays, and skates. In: G. WEST, D.J. HEARD and N. CAULKETT, eds. Zoo animal and wildlife immobilization and anesthesia. Iowa: Blackwell Publishing, $649 \mathrm{p}$.

WEINERT, N.C., VOLPATO, J., COSTA, A., ANTUNES, R.R., OLIVEIRA, A.C., MATTOSO, C.R.S. and SAITO, M.E., 2015. Hematology of Nile tilapia (Oreochromis niloticus) subjected to anesthesia and anticoagulation protocols. Semina: Ciências Agrárias, vol. 36, no. 6, pp. 4237-4250. http://dx.doi. org/10.5433/1679-0359.2015v36n6Supl2p4237.

WOODY, C.A., NELSON, J. and RAMSTAD, K., 2002. Clove oil as an anaesthetic for adult sockeye salmon: field trials. Journal of Fish Biology, vol. 60, no. 2, pp. 340-347. http://dx.doi. org/10.1111/j.1095-8649.2002.tb00284.x. 